\title{
SWORN VIRGINS OF THE BALKAN HIGHLANDS
}

MARIJA BRUJIĆ AND VLADIMIR KRSTIĆ

Once widely spread in the Dinaric Mountains part of the Balkan Peninsula swearing to virginity was a social and cultural custom recorded among all groups inhabiting the area. In the absence of a capable adult man in the household, a daughter would take over his social role by 'becoming' a man. The standard explanation is that the function of this practice is enabling the continuation of the household's economic, social, and religious activities. We argue that this explanation fails. A better explanation is that, because the lack of a particular kind of a man (competent and honourable) was perceived as a shame in these societies, the primary reason for swearing to virginity was saving family honour. Keywords: honour, social anomaly, sworn virgins, traditional ritual, Western Balkans
V̌́asih široko razširjena prisega nedolžnosti v Dinarskem gorovju na Balkanskem polotoku je bila družbeni in kulturni ritual, dokumentiran med vsemi skupinami na tem območju. Po tem ritualu naj bi hči, če v družinskem gospodarstvu ni bilo sposobnega odraslega moškega, prevzela njegovo družbeno vlogo, tako da je 'postala' moški. Po standardni razlagi je funkcija te prakse omogočiti nadaljevanje gospodarskih, socialnih in verskih dejavnosti gospodinjstva. Avtorja menita, da ta razlaga ni ustrezna. Po njunih ugotovitvah pa je glavni razlog za prisego nedolžnosti reševanje družinske časti, saj je odsotnost posebne vrste moškega (sposobnega in častnega) $v$ teh skupnostih sprejeta kot sramota.

Ključne besede: čast, družbena anomalija, zaprisežene device, tradicionalni rituali, Zahodni Balkan

\section{INTRODUCTION}

Female swearing to virginity was specific for patriarchal tribal societies in the Dinaric Mountains parts of Montenegro, Northern Albania, and southern Serbia (Kosovo) but sworn virgins were also found in Bosnia-Herzegovina, North Macedonia, and Serbia (Raška district and Vojvodina region) (Barjaktarović, 1948; Gušić, 1958; Vukanović, 1961). The phenomenon was recorded among Muslims (Albanians, Bosnians, and Turkish Roma), and Orthodox (Serbs and Montenegrins) and Roman-Catholic (Albanians) Christians.

Because men were respected more highly than women, swearing to virginity was approved by local communities and these women would be socially accepted as men sometimes, no one would even know that they are women. Two types of sworn virgins exist: biological women who were predestined to become men from their infancy or early childhood (typically by their parents), "vow imposed," and women who decided to take upon a social role of a man, "vow accepted" (Barjaktarović, 1966; Grémaux, 1994). When there was no adult man in a household, a daughter would "replace" him and take his role as the household head. She would vow to virginity, cut her hair, wear men's attire, and would completely renounce her status as a female, including marriage and motherhood. 
That said, notice that this gender change was predominantly in the social and culturalsymbolic sphere (Šarčević, 1999) and it should not be mistaken for simple gender-crossing.

There are many, sometimes incongruent, terms denoting Dinaric sworn virgins dressed up as men. The most common are: tobelija, tombelija (Tur., tövbe, a vow), a person bound by a vow; virgjinéshë (Alb., a virgin), a female committed to virginity, an unmarried woman; vajzë e betuar (Alb., a sworn girl); murgéshë or morga (Alb., a nun); other Albanian terms are burrneshë, tybeli, mashkullore. South Slavs (Serbs and Montenegrins) also used the following names: ostajnica (she who stays [in the paternal household]; unmarried woman), virdžina (a female committed to virginity); cura (a girl); zavetovana devojkalzavjetovana djevojka (sworn virgin); and muškobana (mannish woman) (Heneberg-Gušić, 1930; Vukanović, 1961; Gavrilović, 1983; Đorđević, 1984 [1930]; Dickemann, 1997; Šarčević, 1999; Young, 2000; Vince Paulla, 2014).

Unfortunately, not much historical and ethnographic data on sworn virgins exists. Although some believe that this tradition was ancient (Heneberg-Gušić, 1930; Vukanović, 1961), it probably emerged in $15^{\text {th }}$ century (Gavrilović, 1983; cf. Young, 2000). The first mention is in ancient Albanian oral traditions, Kanun (Laws of Lek Dukagjin), which were written down and codified in the first part of the $20^{\text {th }}$ century (Young, 1998). The earliest written sources are from the $19^{\text {th }}$ century (Medaković, 2001 [1860]; Von Hahn, 1867). While there might still be a small number of sworn virgins (some of the last were recorded at the beginning of the $21^{\text {st }}$ century in Montenegro and North Albania), the ritual will perish soon.

Most social and cultural anthropologists argue that their role was socio-economic. We will discuss these proposals and argue that they are unsatisfactory. Sworn virginity is a response to a problem, a cultural anomaly generated by the lack of the right kind of a man (not just any man), and the received solutions are explaining the consequences of the problem rather than the problem itself. We argue that avoiding familial disgrace caused by not having a competent and honourable man in the household is the cause of swearing to virginity. This man needed to be the defender of the household and an example of chastity, courage, strength, and honour. The socio-economic benefits are the by-product of having a new household head.

Our argument will unfold as follows. After a preliminary discussion and a brief comparison with similar phenomena, we present our classification of the phenomenon, and then discuss some of its main features. After, we discuss the received explanations and argue that they fail. We argue that saving the family honour is the main motive behind this practice and that this is done by way of providing the family with a praiseworthy household (male) head. 


\section{DESCRIBING THE PHENOMENON}

\section{GENERAL CHARACTERISTICS}

Generally speaking, a sworn virgin is a young virgin girl, but a grown woman can also become a sworn virgin. Their special status normally includes the following: man's attire, name, and haircut; male social obligations (e.g., bearing arms and participating in battles and blood feuds; participating in the tribal, clan, and village meetings; taking care of family religious cults); and male privileges (e.g., smoking tobacco, drinking alcohol, socializing with men, being able to enter men's premises). According to the customary law, they were given partial or full legal and working abilities otherwise inaccessible to women (Gavrilović, 1983). Most importantly, they would act as household heads when necessary: they would own the family property and become respected both by men and women of their local community. There were some limitations, however: they could not vote in community meetings and could not be killed in battles and vendettas (Kaser, 1994; Tarifa, 2007).

It is very difficult to provide a precise definition of sworn virginity. Firstly, the (English) term itself covers various institutionalized behaviours of women dressed as men. Secondly, some of the sworn virgins did not refer to themselves in such a way (but others in their community or scholars described them as such), and some would hide their real gender. Finally, many features of this phenomenon are case-sensitive.

Most sworn virgins were uneducated and from rural Balkan regions, but they could also be found in North Albanian towns or among educated women (Barjaktarović, 1966; Young, 2000). There were differences in their appearances and behaviour. Some would take a male name whereas others were called by their original, female name. Some referred to themselves in the masculine and others in the feminine gender form. The majority wore male clothes but there were some exceptions. Most sworn virgins spent time with men and looked down on the company of women. Some were even buried in male clothes and according to the funeral rites reserved for men. However, some would spend more time with women, only entered female space, and were buried in female clothes. Many sworn virgins used profanities, smoked, and drank, but others were famous for their virtuous life. In many cases, people who did not know their actual sex did not even know that they were biological women. Finally, most sworn virgins were proud of their status, and claimed to be happy with their man's life and with having a decision-making role (see Barjaktarović, 1948; Vukanović, 1961; Gušić, 1976; Grémaux, 1989, 1994; Young, 2000; Vince Paulla, 2014). However, some were aware of its negative aspects, expressed doubts, and were "unhappy in their identities" (Dickemann, 1997; Vince Paulla, 2014).

This all makes explaining the origin of the phenomenon very difficult. The best strategy, we suggest, is to (i) identify and understand the main reasons for swearing to virginity and to (ii) understand the society that gave birth to this practice. But, let us first see what swearing to virginity is not. 


\section{GENDER AND SEX}

For contemporary anthropologists of gender, kinship, and feminism, gender is not a result of biological consequences but is rather a cultural construct and a social role, which depends on a specific social system (Yanagisako, Collier, 1987; Moore, 1988; Mascia-Lees, Johnson Black, 2017; see, Bošković, 1996; Jovanović, Naumović, 2004; Brković, 2020). When discussing 'male' and 'female,' they take social contexts into account and include historically-based variations in gender behaviour in particular societies. Sworn virginity ${ }^{1}$ should be understood from within this framework. What we mean is that a sworn virgin was a female by her biological characteristics who herself has chosen or was predestined by her family to socially act as a man. Therefore, as an "honourable male," she was accepted by her community as a "social male/man" (Grémaux, 1994). In this respect, various ethnographic accounts show (see below) that gender identity did not have to align with the sworn virgin's gender display (Šarčević, 2004). Predrag Šarčević gives an example of Stanica Daga Marinković, who felt like a female (her gender identity) and would never hide her sex.

Her identificatory display as a man has always been modified by referring to herself as a woman. Finally, her moral satisfaction sprung not from being able to deceive others with her looks but from the fact that socially she was treated as a man despite her sex. (Šarčević, 2004: 140)

But many sworn virgins - Mikaš Karadžić, for example - referred to themselves in the male gender and acted as if they felt like men. People would not dare to call Mikaš a woman; even when she died, people used both 'he' and 'she' when referring to her (Grémaux, 1989). Mikaš never had sexual relationships with men or women. Nonetheless, although she publicly despised women, according to René Grémaux's informants, women did attract her sexually. This may explain why Grémaux $(1989,1994)$ considers sworn virgins as "transvestites" saying that they might be seen as a third gender, because they were "between and betwixt" male and female gender.

Other scholars, however, reject his hypothesis - and rightly so. This behaviour was not an individual act of expressing sexual tendencies but rather a respected social act and a privileged position. Gender-crossing (Young, 2000) and cross-dressing (Dekker, Van de Pol, 1989) involve a personal choice and are not associated with a social role. In contrast, sworn virgins were a social institution accepted by the wider community, codified by traditional common law, and endemic for the Dinaric region (Grémaux, 1994; Dickemann, 1997; Vince Pallua, 2014). Antonia Young (2000: 59) correctly writes that some lesbian inclinations recorded among sworn virgins were meant "to strengthen their cases for being

1 Isidora Popović (2018) discusses from Foucault's position a case of Stana Cerović (1936-2016), one of the last recorded sworn virgins. However, because the text is in Portuguese, we were unable to critically engage with her arguments. 
treated and respected as males." Sworn virgins are "social men" whose vows to chastity were approved by the local community (Dickemann, 1997; Young, 2000; Vince Pallua, 2014). Their strict community in many instances even encouraged social inversion of gender. In contrast, the $16^{\text {th }}-19^{\text {th }}$-century female cross-dressers and transvestites occupied a marginal social position, had primarily psychological and sexual reasons for hiding their female sex, and were socially and legally unaccepted in Europe (Dekker, Van de Pol, 1989; Kaser, 1994).

There are indications that some sworn virgins had homosexual affinities and some even homosexual relationships (e.g., Vukanović, 1961) but those indications are very rare, unclear, and thus speculative. In fact, there is no firm data on either their hetero- or homosexual relationships (Dickemann, 1997). Neither Grémaux (1989) nor Young (2000) found traces of lesbianism among sworn virgins. Nevertheless, Young does admit that, even if there were some sexual activities, it would be very difficult to detect them because sworn virgins hid their emotions and feelings. The last sworn virgins of the $21^{\text {st }}$ century rejected the idea of their lesbianism and did not want their lives to be scrutinized by "the Westerners" (Vince Pallua, 2014).

Finally, whether they had such affinities is an irrelevant research question: this social practice was definitely not invented to regulate homosexual affinities of women since, if this were the case, we would have male sworn virgins as well. We now proceed to discuss practical reasons for swearing to virginity.

\section{MAIN MOTIVES}

There are several main reasons (motives) for swearing to virginity: lacking an adult male in the family, breaking up an engagement, divorce, or blood feud. We discuss them in turn.

\section{No adult male in the family}

Typically, in patriarchal societies, a daughter would marry and become a part of another household. The son would remain in the house as the new head. He would take care of the parents, organize the life of the household, and continue to celebrate the family's religious rituals. In cases when there were no male descendants, the female-to-male gender change would prevent the so-called "dying of the household" (Đorđević, 1984 [1930]); the household would "die" because it would be left without a head. As a "replacement for a son," the sworn virgin would become the head of the household and its legal heir; she would take care of the parents and raise younger brothers (Heneberg-Gušić, 1930; Barjaktarović, 1948; Young, 2000). This was the most frequent reason for swearing to virginity.

The decision to "convert" into a male could be imposed on the child at birth or early in her childhood. Nonetheless, a daughter could make that decision herself. All sworn virgins that Young (2000) met in Northern Albania in the 1990s willingly took this role. There were either no household heads or no adult men who could become grown soon enough. The case of Lule was particularly interesting. In a family of 10 surviving children, there 
was only one son and he was unfit for a household head. Therefore, Lule took over the role of a man and the household head. Reflecting on her life, Lule said that she has always behaved like a boy, that she never wanted to marry, and that she never regretted her choice.

In other instances, there were no sons in the family. Milica-Mikaš Karadžić, a 75-year old sworn virgin from the village of Palež in Montenegro, is a famous case. Because her father had died in a battle before Milica was born, her father's mother and her mother prepared her to be a male "master of the house."

Milica was called with a male form of her name, Mikaš, and nobody has ever, not even today, called her differently. [...] She occupies herself only with male jobs, celebrates her father's Patron Saint [krsna slava] [...]. When she was young she went to battles, in short, in everything she behaves as a man-head of the household. All her surroundings respect her for that. As she could not marry, she remained in the house alone, and in her old age was very poor. [...] She herself would find it a grave insult if she were called a woman. (Heneberg-Gušić, 1930: 10-11)

Another example is Nurija-Drko, documented by Mirko Barjaktarović (1966) who knew her personally. When the fourth daughter of a married couple Aljo and Nurka Memić from Gusinje was born in 1910, Aljo decided to give her (Nurija) a man's name, Drko, and to raise her as a son. Before Aljo died, he told the 12-year old Drko to "stay in the house, cultivate the land and take care of his mother and not listen to what the others are talking about" (Barjaktarović, 1948: 347-348). Drko remained faithful to his father's wish, running the household. His 8-year old nephew started living with him in 1940 (i.e., with his 'uncle') so that Drko would leave him his property after his death. However, Drko died in 1956 without formally and legally adopting his nephew.

Not all sworn virgins respected their vows. Barjaktarović (1966) and Grémaux (1989) mention a case of Fatima from Metohija (today's Kosovo). Fatima's father died soon after her birth in 1926 and her mother continued to treat her as a son, keeping this a secret. In 1951, Asllan Asllani kidnapped her while she was still in man's clothes and married her. Although her mother died without forgiving her for losing her 'son,' Fatima claimed that she was happy to be a woman and a mother.

\section{Avoiding Marriage}

According to Albanian oral traditions, in case of breaking off an engagement, the girl could not marry again to avoid dishonouring her fiancé's family. If she would re-marry, her first fiancé and his family were allowed to kill her male relatives in a blood feud. The most common reason for breaking off an engagement is avoiding an arranged marriage (Vukanović, 1961; Barjaktarović, 1966; Tarifa, 2007). Tatomir P. Vukanović gives ethnographic data on two Albanian sworn virgins whom he had met in 1936 and 1947 in 


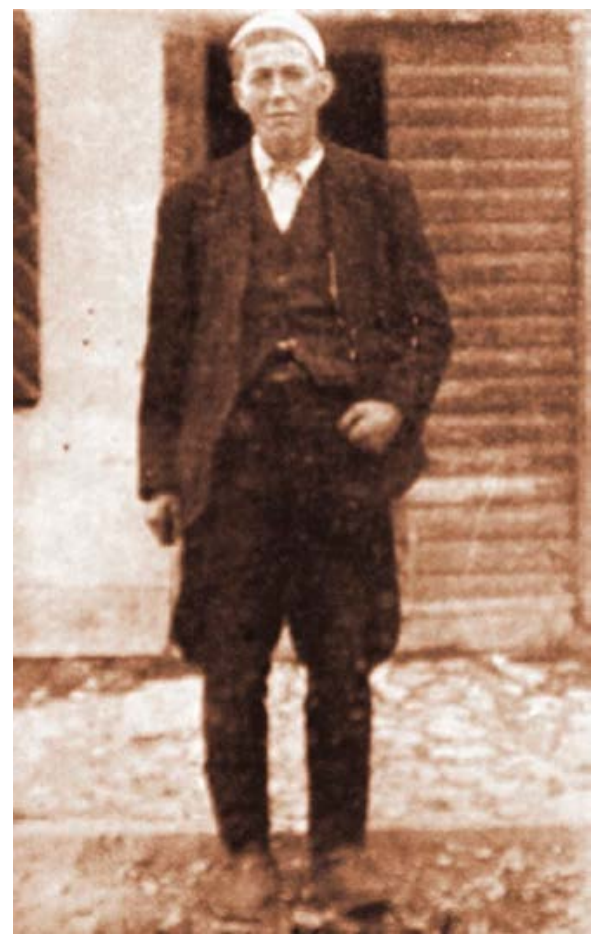

Figure 1. Nurija Drko.

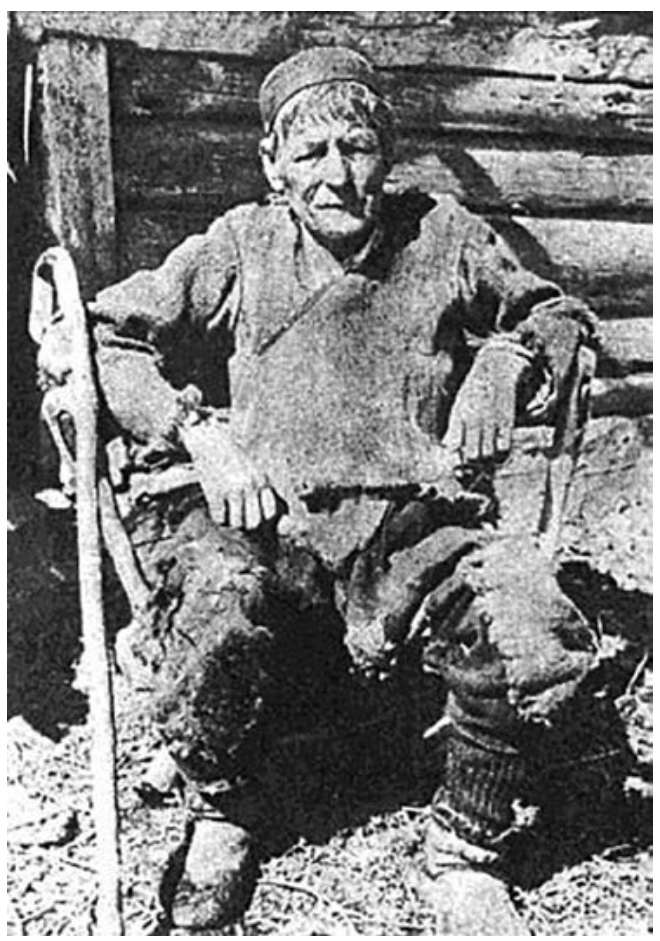

Figure 2. Mikas Karadžić.

Metohija (Kosovo). Because their brothers were underage, both Sali (Salija) and Hyl took man's robes, cut their hairs, and refused to marry their fiancés:

[Salija] [...] took a male name Sali. All her life she remained in her parental house, raised her brother's children, and was the head of the household [...] She did all the male jobs, in the house and the field, living a male's life for years. (Vukanović, 1961: 91)

Hyl, however, kept her female name and she spent time only with women. "The village asked her a couple of times to get married, but she refused. And her mother advised her many times to marry, but she would not listen" (Vukanović, 1961: 91).

While these are examples of Albanian girls, the practice of avoiding a marriage was known among members of other religions. This could even be influenced by the girl's mother. In 1939, Barjaktarović (1948) met Đurđa Popović in Montenegro, who was engaged to be married. Since the mother wanted to have a son in the house, Đurđa decided to stay with her parents, taking up a man's role. After her parents died she stopped receiving her father's pension and fell into poverty. 
Finally, a sworn virgin could become a disappointed girl whose boyfriend died, got killed, or married another girl; a widow who needed to raise her children; a divorcee; a girl who wanted to avoid ill-treatment in future marriage and opt for more freedom in everyday life; a girl with a physical anomaly, or one that was seen as not being fit for marriage/not being capable of having children (Vukanović, 1961; Barjaktarović, 1948, 1966; Dickemann, 1997).

\section{A Blood Feud}

In North Albania, the blood feud represented an institutionalized form of vengeance and a way of regulating social relationships; it largely correlated with the existence of sworn virgins (Simić, 1967; Denich, 1974). A similar custom was recorded among Montenegrins and Muslims in Montenegro, Kosovo, and parts of Herzegovina. When a man was killed, the killer's male relatives remained in the house to avoid getting killed in response (Vukanović, 1961). Therefore, a daughter had to take over a man's social role, wear man's clothes, cut her hair short, and do male jobs.

\section{The Influence of the Roman-Catholic Church}

In North Albania, there was a custom among catholic Albanian girls to remain celibate as a way of rejecting a fiancé and arranged marriage. Grémaux believes that this type of female celibacy was a result of a Franciscan friars' influence on customary law in the cases when girls wanted to live a chaste life. Later on, it was adapted to fit local circumstances by adding an oath to virginity and cross-dressing: 'once established, this practice, religious in origin, was to slip out of the Franciscans' control and become increasingly profane' (Grémaux, 1992: 371). These examples should be taken with a grain of salt. They show that swearing to virginity was a case-sensitive phenomenon and that in some cases there are several plausible explanations or several reasons for swearing to virginity.

\section{UNDERSTANDING THE SOCIETY}

This type of swearing to virginity was approved by the traditional patriarchal societies. Although this custom occurred among different ethnic, religious, and cultural groups of the Dinaric region of the Balkan Peninsula, many common features unite this isolated region. In fact, there are many similarities between Albanian and Montenegrin tribes and their customary laws, which influenced one another other to an observable extent (Simić, 1967; Gavrilović, 1983; Vince Pallua, 2014). These similarities are important for our argument and they need to be highlighted.

These were patriarchal and rural (pastoral-agricultural) societies. They were patrilineal (descent was calculated through the male line and only men inherited material and spiritual property), patrilocal (the wife lived in her husband's house), exogamous (the wife 
was usually from another village), and warrior societies, who were all under the Ottoman rule for several centuries (Kaser, 1994; Young, 2000; Šarčević, 2004; Tarifa, 2007). Their social organization was kin-tribal: the kinship group had an important role and reputation; the household unit included extended family members (sons and their families); and men possessed power while women were subordinate (Vukanović, 1961; Barjaktarović, 1966; Simić, 1967; Grémaux, 1989; Young, 1998; Šarčević, 1999). In short, the household was a basic unit in the society and the father or the eldest man was the head of the family, and the proprietor of the household. He enjoyed the greatest respect and was the source of the family's pride and self-esteem. Men were higher in social rank than women regardless of age (Simić, 1967; Denich, 1974).

The traditional customary law had a vital role in organizing private and public life (Dekker, Van de Pol, 1989) and this law was based on honour. Honour (ćast) and selfesteem (obraz) regulated Montenegrin society. As Andrei Simić (1967) remarks, these concepts are "expressed collective responsibility of every member of the clan or family and [they] depend not only upon his actions but also those of his ancestors and descendants." Similarly, while describing the north Albanian society, Tarifa (2008) says that honour was "something prized above personal liberty, or even life itself." Honour was to be protected at all costs, even by blood.

Given this dire need for having strong, exemplar men in a household, when it comes to having children, the household honour was at stake. It was honourable to have male children and the lack of a strong adult male heir was shameful (Young, 2000: 57). As Grémaux (1989: 160) observes, "in everyday life, parents who failed to produce a son suffered a loss of status, or downright ostracism." According to Barjaktarović (1966: 284), "a high number of female children in the house were considered as a misfortune and a curse. Female children were not even counted as 'children'." A woman was a "social outsider," being "little more than the property of her father or husband" (Dekker, Van de Pol, 1989; Grémaux, 1994). The status of a bride was likewise inferior until she would give birth to a son (Young, 2000). This all puts swearing to virginity into a very important perspective. So, let us try explaining it.

\section{EXPLAINING SWORN VIRGINS}

Identifying reasons behind swearing to virginity is difficult. This is not a contemporary phenomenon, and thus relevant ethnographic studies cannot be repeated. Moreover, the available data gives little information on a specific female's personal and intimate stance towards her decision to remain celibate, give a vow, or engage in cross-gendering and maledressing. Although some scholars knew sworn virgins they interviewed (e.g., HenebergGušić, 1930; Barjaktarović, 1948; Gušić, 1958, 1976; Vukanović, 1961; Barjaktarović, 1966; Gavrilović, 1983; Grémaux, 1989; Young, 2000; Šarčević, 2004), we do not have enough ethnographic testimonies. 
Moreover, the researchers who conducted the fieldwork did not spend extensive amounts of time with the sworn virgins. Thus, they did not have time to get to know them well and could not observe their actions on a daily basis. It follows they were probably unable to gain their trust. Young, who conducted fieldwork among Albanian sworn virgins during the 1990s, had to be accompanied by an interpreter who could have kept some sensitive issues or important aspects of this custom hidden from her. Therefore, many scholars used scholarly literature and the latest media information in order to describe and interpret this custom (see Dickemann, 1997; Djajic Horváth, 2003; Tarifa, 2007; Vince Pallua, 2014).

To note, data to offer a reliable explanation of the phenomenon appears insufficient. In what follows, we first examine the most frequent explanations, and then, argue that, just as blood feud is an honour killing (i.e., saving the family's face by killing a relevant person), sworn virginity is an honour gender change.

\section{THE RECEIVED VIEWS}

Generally, explanations offered by Yugoslav scholars in the first part of the $20^{\text {th }}$ century were later either refuted or abandoned by the authors themselves. The predominant view was that the customs originated in the $15^{\text {th }}$ century - which correlates with the beginning of the Ottoman rule of the area. Economic reasons were listed as the main motive for swearing to virginity (as men they would be able to work, own land, etc.). The idea is that because of their unequal position, some women were forced to live as men and lead their clan economy when needed (Vukanović, 1961).

In his early writings for example, Barjaktarović (1948) states that this custom had an economic purpose: to preserve household and property for another generation, and to maintain various familial, ancestral, and domestic religious cults - since only men could do this. Later, however, Barjaktarović (1966: 281) realises that this explains only some cases. Marijana Heneberg-Gušić (1930) first describes sworn virgins as a "relic of the patriarchal society," but she later says that they originate from priestesses and prophetess of female PaleoMediterranean cult (Gušić, 1958; 1976). ${ }^{2}$ Similarly, Vukanović (1961) understands sworn virgins as similar to women warriors (e.g., Amazonian girls), and writes that sworn virginity was a "fossilized custom" that originated during matriarchal society. However, there is no historical evidence of connections between mythological Amazonian girls, sworn virgins, and the existence of the presumed matriarchal society, especially knowing that swearing to virginity was neither common to all South Slavs nor restricted to Slavs (Barjaktarović, 1966; Gavrilović, 1983; Kaser, 1994; Vince Pallua, 2014). Thus, these two explanations fail.

Notwithstanding their differences, the majority of researchers agree that the cause of swearing to virginity can be found in the underlying logic of the Dinaric patriarchal societies and their standardized behaviours and roles ascribed to men and women. Karl Kaser

2 Gušić (1976) suggests that this was a way for unmarried girls to avoid the shameful position of a spinster. 
(1994) prominently writes that sworn virgins (Ger. Mannfrau) were designed to remedy the structural error of the patriarchal system and to provide a continuation of a male hereditary line when there were no direct male descendants. A whole family of solutions is based on this thesis. Šarčević, for instance, writes that this phenomenon emerged as

an effort to reconcile 'anomalies' that originate from the strict respect for an ideology that devaluates women, with the fact that the very survival of the community and the whole cultural system in some situations depends on women. (Šarčević, 1999: 43)

Also, Barjaktarović (1966) sees them as a consequence of patriarchal mentality and clan system. These tribal-clan communities favoured men, approved self-sacrifice for the sake of others (e.g. for younger brothers or next of kin), and underestimated the position of women. And because of the underdeveloped economy, hard labour force was needed (similarly, Vukanović 1961; Vince Pallua 2014). Young (2000) also sees the economic factor as the primary motivation. The majority of sworn virgins she spoke with said that the household needed its head and no suitable adult man was available. She further adds that the substitution of men was necessary since many men died in blood feuds and, lately, many men migrated abroad. Similarly, for Fatos Tarifa (2007) and Jelka Vince Pallua (2014), sworn virgins were a solution for the lack of men (numerous blood feuds and wars) and their function was labour and war force.

According to Ljiljana Gavrilović (1983), the custom was generated by the socioeconomic needs of the clan-tribal society between the $15^{\text {th }}$ and the $19^{\text {th }}$ century: they were given temporary or full legal and business rights and their existence regulated relationships at the levels of family, clan, and community/tribe, all of which was necessary for the clan system to function. On the communal level, permanent celibacy had an integrative function. By obtaining the status of men, sworn virgins could carry arms and join battles against the Turks or other clans. Also, they would balance the number of young men and women capable of getting married, since many men died in battles or blood feuds. With the decline of the clan society in the second half of the $20^{\text {th }}$ century, social changes and globalization, the institution of sworn virgins lost its role. With the emancipation of women, the disintegration of the blood feud, and the introduction of new laws it became possible for daughters to inherit family property and they were given full legal and working rights (Gavrilović, 1983). Gavrilović supports her thesis that permanent celibacy had an integrative function with historical data and her own ethnographic research from 1983 in the Raška district in Serbia, where she only found one sworn virgin.

Finally, for Vince Pallua (2014), sworn virginity is a consequence of the social and economic needs of the region's highly patriarchal tribal societies and archaic customs. Because the $15^{\text {th }}$ century involved a collapse of national feudal states in the region, Ottoman intrusion, and resurgence of tribal organization, the role of sworn virgins was to re-establish social and economic balance on the community and family levels. When there were no mature 
men in the household, they sacrificed themselves for the community's wellbeing, replaced men, and protected the survival of the community and the family. The perpetuation of the lineage was enabled with the male cousin who would continue to live with the sworn virgin and would, after her death, take over the role of the household head.

Below, we show that these explanations fail.

\section{Why the Received Views Fail}

To recall, according to Gavrilović (1983), swearing to virginity was used mainly as an option for women to gain legal and business (economic) rights during historical periods when they did not have access to these privileges. Gavrilović supports her position with the fact that there was a lack of sworn virgins during her ethnographic research at the beginning of the 1980s: her explanation is that this was a time when women already had working and legal rights.

However, Gavrilović's research was conducted in the Raška district of Serbia where there were only a few sworn virgins. Even older ethnographic data does not record many cases there. In reality, the existence of sworn virginity in Raška is an anomaly and no one really knows how the phenomenon got there. Moreover, some sworn virgins lived (and died) in poverty after their parents died, such as Đurđa Popović or Mikaš. If their motives for swearing to virginity were socio-economic, they would have tried to get married or start some business activities instead. Finally, not all sworn virgins took and officially adopted their male cousins, one example is Drko. Therefore, it remains unclear for the sake of whom these women took upon the male economic role: it was not for themselves since if this were the case, disregarding old age conditions would make no sense, it was not for the sake of their non-nuclear family since if this were the case, sworn virgins like Drko would have adopted nephews. Cases like Drko also speak against Kaser's (1994) and Vince Pallua's (2014) idea that the role of sworn virgins is the continuation of patrilineality.

Young (2000) and Vince Pallua (2014) suggest that sworn virgins were a solution for the lack of men. However, it is highly unlikely that, during several centuries when this custom extensively occurred, the lack of men was so dire. In fact, several authors claim that the opposite was the case (Durham, 1910; Tarifa, 2007). Mary E. Durham (1910) lists two good reasons against this hypothesis. First, because of a very young age at which girls were married, there was a tremendously high death rate in childbearing at the beginning of the $20^{\text {th }}$ century. Second, carefully kept church registers of baptisms and deaths (from the same period) show that a considerable excess of males was born and reached maturity. True, the male death rate from gunshot wounds was also high, but not high enough to justify the idea that there was such an excessive demand that women had to "become" men. And it seems safe to assume that this was all the case even before the $20^{\text {th }}$ century.

Barjaktarović (1948) argues that the female to male cross-dressing could not have served as a protective tool against Turkish sexual assaults. This custom was practised among Muslim women, too, and they did not have to fear this violence. More importantly, Gušić 
(1976) and Tarifa (2008) note that this geographical area was distant, frequently without roads and inaccessible even for the Turks, who had only "nominal authority" over it. The fact that the Turks maintained a low degree of authority over this area not only further supports the view that sworn virginity was not a protective mechanism, but also shows why men, and the roles they occupied, were so important in the Dinaric societies. In a situation in which the state was unable to guarantee rights, communities needed to create disincentives for violence and dishonesty by themselves (hence, the blood feud for example).

Vitally, we are not talking about a lack of just any kind of man. Mildred Dickemann (1997) discusses the idea of a sworn virgin as a "surrogate son" who should inherit the father's household as a temporary solution. However, after her father's and sworn virgin's death, the inheritance would typically go to her nearest male relative. Besides, many women would swear to virginity even when the household would have a male heir; in the case of a younger brother or a man of qualities unfitting for head of the household. Therefore, the reason is not the absence of a biological man but rather of a particular kind of a man the society and the household needs. This man is not only the defender of the household but also an overall praiseworthy agent, a pride of the household - since a tribal household is only as good as its head. He would contribute to his society not only by safeguarding justice but also by being an exemplar of just and praiseworthy behaviour, a role model. Below, we purpose this line of reasoning further.

\section{OUR HYPOTHESIS: SAVING HONOUR}

The received solutions provide practically rational reasons for becoming a sworn virgin; that is, rational in the sense that, while swearing to virginity is not the desired option, it is the best of all available alternatives. However, not all human behaviour is guided exclusively by practically rational reasons and a decision to do something that makes no practical sense (e.g., spending the end of your life in poverty only to hide your gender) may make lots of sense from within the perspective of ethical norms and social conventions of a given society in a certain historic context - especially if those norms and conventions have a higher authority than practical rationality in that society.

What all of the above solutions fail to take into account is the fundamental role of honour and justice in these societies. We argue that the function of sworn virgins was correcting a social and cultural anomaly by providing the right kind of a man, a man who is competent and honourable, and not primarily due to socio-economic reasons (simply lacking of $a$ man), but rather because of traditional (and ultimately) moral demands. The man the household was expected to be its defender and an example of chastity, courage, strength, and honour. The role of this particular man, an exemplar in many ways, is to protect the honour of the household. The need to close this gap, to control this anomaly in society, caused this custom and sustained it for so long, namely almost six centuries. Allow us to propose and explain the nature of the given anomaly and how it was controlled. 
A social and cultural anomaly is something that does not fit into a wider cultural system of shared values. Mary Douglas (1984 [1966]), discusses several strategies of controlling anomalies. First, a community can choose between cultural interpretations of cultural events and categories, and aberrant forms to reduce or eliminate the anomaly. Second, the anomaly can be physically controlled (or destroyed). Third, the anomaly can be avoided (the book of Leviticus, for instance, mandates avoiding particular animals). Fourth, it can be symbolically controlled by calling the anomalous events dangerous. Finally, it can be incorporated into rituals.

Vitally, the existence of sworn virgins was not an anomaly in a society which favours men; rather, the lack of a particular kind of men was an anomaly in these Dinaric societies. These men were the building block of the Dinaric societies: because the Ottoman empire could not guarantee everyone's rights (due to the extremely inhospitable terrain, Ottoman rule was only nominal), household heads were the ones whose role was to secure (via honour) a just and fair society and, knowing that justice is basis for any functioning society across time, the role of men worthy to exemplify these heads was vital. And because the role of such men was essential to the successful functioning of the society itself, a household without such a man was an anomaly and it also presented a danger for the life of society itself. That is, a household without a praiseworthy man disturbs the homeostasis of the tribal system - since one of its units becomes dysfunctional. These patriarchal systems regulated the anomaly by physically taking control over it (Douglas's second way of controlling the anomaly): they would introduce women who socially acted as men. But why did females accept this role?

According to Tarifa (2007), vowing to virginity was a compensatory mechanism of giving away female gender, social role, and the privilege of motherhood to obtain male privileges, roles, and entitlements. This hypothesis is plausible only on the condition that all of these women had seen male social possibilities as privileges worth obtaining, which is very hard to accept and, concerning the variety of the given ethnographic cases, impossible to generalize. This problem becomes especially salient in the light of the fact that many of these women were literally forced to become sworn virgins, either as young girls or by their parent's explicit command or some kind of emotional manipulation (e.g., a parent's deathbed wish).

Our analysis indicates that the real reason for swearing to virginity was saving honour; these women accepted such roles because they practically had no other choice, this was the only way to save the family's honour (and some were very happy to accept this burden). The honour that needed to be saved could be (i) the honour of the sworn virgin's household unit (e.g., lack of the right kind of male, breakup of an [arranged] marriage) or (ii) the honour of a closely related household unit / clan (e.g., the honour of the 'groom's' family). In the second case, wider social contacts were regulated and her act would be accepted by her future fiancé's or husband's family without provoking a blood feud: because the groom's honour was left unharmed, the justice system was left unharmed. On closer inspection, then, even the case in which a girl voluntarily decides to become a sworn virgin "for her 
own practical benefit" and to protect her "own honour," we see that men's honour is also being protected; in particular the honour of her father, who did not break his word, and the honour of her (potential) husband, who was not left dishonoured by her decision (i.e., she did not reject him). And by protecting the men's honour, the custom protects the honour of their respective households and thereby keeps the system of justice in harmony.

Avoiding a disgraceful position by having a female member of the family swear to virginity entailed social and economic positive outcomes, of course. However, that was not the main reason for swearing to virginity. Girls were equally capable of doing male jobs in female clothes; they did not have to dress as men. Also, if they wanted to go to war, they could have pretended to be men; they did not need to vow to virginity. In the Balkans in fact, many women did so without swearing to virginity: one famous example is Milunka Savić who enlisted in the Serbian Army in 1912 under the male name Milun. Thus, a practical benefit was not the root cause of this custom. The girl's swearing to virginity was essentially a highly moral act that would, in virtue of controlling the anomaly in the honour-based social structure, generate certain social consequences - but as by-products.

\section{CONCLUDING REMARKS}

Once a widely spread phenomenon, sworn virgins have probably disappeared by now as a living social group. Against the received literature, we argued that swearing to virginity was not caused and sustained by social or economic demands or a simple lack of men. Its function was not to hide the girl's true sex but rather to hide an existing social anomaly, namely, the lack of the necessary kind of a man. This man needed to be the defender of the household and an example of chastity, courage, strength, and honour. The hypothesis that by controlling the anomaly, the function of swearing to virginity was saving the honour of a particular family (families or clans) explains most instances of this phenomenon without raising core concerns.

The custom of swearing to virginity lost its initial function due to many factors, but principally because of the following two: the state, rather than the households, clans, or communities, gradually became capable of guaranteeing and enforcing justice as fairness. Furthermore, with the industrial modernization, these societies became less isolated and, as a result, various external influences prompted social changes resulting in greater female rights, such as the right to inherit property, and greater female roles.

An underlying limitation of our study is that it was not based on field research, but this is no longer possible at this time. Even if sworn virgins still exist, we do not know how the phenomenon transformed in modernity (these societies are no longer isolated), and relevant influences are impossible to identify. In fact, even data provided by the scholars who have conducted field work should be taken with some degree of reservation, since these specific societies were never particularly open towards outsiders. 


\section{REFERENCES}

Barjaktarović, Mirko. 1948. Prilog proučavanju tobelija (zavetovanih devojaka).Zbornik Filozofskogfakulteta I: $343-352$.

Barjaktarović, Mirko. 1966. Problem tobelija (virdžina) na Balkanskom poluostrvu. Glasnik Etnografskog muzeja u Beogradu 28-29: 273-286.

Bošković, Aleksandar. 1996. Constructing Gender in Contemporary Anthropology. PhD Thesis. University of St Andrews.

Brković, Čarna. 2021. In the Name of the Daughter - Anthropology of Gender in Montenegro: An Introduction. Comparative Southeast European Studies 69 (1): 5-18. https://doi.org/10.1515/soeu-2021-2013.

Dekker, Rudo M., and Lotte C. van de Pol. 1989. The Tradition of Female Transvestism in Early Modern Europe. Houndmills: Macmillan Press Ltd. DOI: https://doi.org/10.1007/978-1-349-19752-1.

Denich, Bette S. 1974. Sex and Power in the Balkans. In Woman, Culture and Society, eds. Michelle Z. Rosaldo and Louise Lamphere, 243-262. Stanford: Stanford University Press.

Dickemann, Mildred. 1997. The Balkan Sworn-Virgin: A Cross-Gendered Female Role. In Islamic Homosexualities: Culture, History and Literature, eds. Stephen O. Murray and Will Roscoe, 197-203. New York: New York University Press.

Djajic Horváth, Aleksandra. 2003. A Tangle of Multiple Transgressions: The Western Gaze and the Tobelija (Balkan Sworn-Virgin-Cross-Dressers) in the $19^{\text {th }}$ and $20^{\text {th }}$ Centuries. Anthropology Matters Journal 2. https://www.anthropologymatters.com/index.php/anth_matters/article/view/119/234.

Douglas, Mary. 1984(1966). Purity and Danger: An Analysis of the Concepts of Pollution and Taboo. London, New York: Routledge.

Durham, Mary E. 1910. High Albania and its Customs in 1908. Journal of the Royal Anthropological Institute 40: 453-72.

Đorđević, Tihomir. 1984 (1930). Našnarodni život 6, 276-278. Beograd: Prosveta. [Originally published in Sveslovenski zbornik (Zagreb).]

Gavrilović, Ljiljana. 1983. Tobelije: Zavet kao osnov sticanja pravne i poslovne sposobnosti. Glasnik Etnografskog muzeja 47: 67-80.

Grémaux, René. 1989. Mannish Women of the Balkan Mountains: Preliminary Notes on the 'Sworn Virgins' in Male Disguise, with Special Reference to Their Sexuality and Gender-Identity. In From Sappho to De Sade: Moments in the History of Sexuality, ed. Jan N. Bremmer, 143-172. London: Routledge.

Grémaux, René. 1992. Fransciscan Friars and the Sworn Virgins of the North Albanian Tribes. Religion State \& Society 20 (3-4): 361-374. DOI: https://doi.org/10.1080/09637499208431565.

Grémaux, René. 1994. Woman Becomes Man in the Balkans. In Third Sex, Third Gender - Beyond Sexual Dimorphism in Culture and History, ed. Gilbert Herdt, 241-281. New York: Zone Books.

Gušić, Marijana. 1958. Ostajnica-tombelija-virdžina kao društvena pojava. In Treći kongresfolklorista Jugoslavije držan od 1-9.IX.1956.g. u Crnoj Gori, ed. M. S. Lalević, 55-64. Cetinje: Savez folklorista FNRJ.

Gušić, Marijana. 1976. Pravni položaj ostajnice-virđineše u stočarskom društvu regije Dinarida.' In Odredbe pozitivnog zakonodavstva i običajnog prava o sezonskim kretanjima stočara u Jugoistočnoj Evropi kroz vekove: Zbornik radova sa međunarodnognaučnog skupa održanog 6. i 7. novembra 1975. u Beogradu, ed. Vasa Čubrilović, 269-295. Beogad: Srpska akademija nauka i umetnosti.

Heneberg-Gušić, Marijana. 1930. Etnografski prikaz Pive i Drobnjaka. Etnološka biblioteka 10:3-17. 
Jovanović, Miroslav, and Slobodan Naumović, eds. 2004. Gender Relations in South Eastern Europe: Historical Perspectives on Womanhood and Manhood in $19^{\text {th }}$ and $20^{\text {th }}$ Century. Münster: Lit Verlag.

Kaser, Karl. 1994. Die Mannfrau in den patriarchalen Geselschaften des Balkans und der Mythos vom Matriarchat. L'Homme 5 (1): 59-77.

Mascia-Lees, Frances E., and Nancy Johnson Black. 2017. Gender and Anthropology. $2^{\text {nd }}$ Ed. Long Grove: Waveland Press.

Medaković, Milorad. 2001 (1860). Život i običaji Crnogoraca. Beograd: Nikola Pašić.

Moore, Henrietta. L. 1988. Feminism and Anthropology. Minneapolis: University of Minnesota Press.

Popović, Isidora. 2018. A virgem juramentada Stana Cerović: Discurso, poder evirilidade. MA Thesis. Brasil: Universidade Estadual do Centro-Oeste - Unicentro: Departamento de Letras de Irati. Available from: http://tede.unicentro.br:8080/jspui/bitstream/jspui/1210/2/ISIDORA\%20POPOVIĆ.pdf.

Simić, Andrei. 1967. The Blood Feud in Montenegro. Essays in Balkan Ethnology (Berkeley) 1: 83-94.

Šarčević, Predrag. 1999. Tobelija: Female-to-Male Cross-Gender Role in the $19^{\text {th }}$ and $20^{\text {th }}$ Century Balkans. In Between the Archives and the Field: Dialogue on Historical Anthropology of the Balkans, eds. Miroslav Jovanović, Karl Kaser and Slobodan Naumović, 135-146. Belgrade, Graz: Udruženje za društtvenu istoriju, Institut für Geschichte der Universität Graz, Abteilung Südosteuropäische Geschichte.

Šarčević, Predrag. 2004. Sex and Gender Identity of 'Sworn Virgins' in the Balkans. In Gender Relations in South Eastern Europe: Historical Perspectives on Womanhood and Manhood in $19^{\text {th }}$ and $20^{\text {th }}$ Century, eds. Miroslav Jovanović and Slobodan Naumović, 125-141. Münster: Lit Verlag.

Tarifa, Fatos. 2007. Balkan Societies of "Social Men”: Transcending Gender Boundaries. Societies Without Borders 2 (1): 75-92. DOI: https://doi.org/10.1163/187188607X163275.

Tarifa, Fatos. 2008. Of Time, Honor, and Memory: Oral Law in Albania. Oral Tradition 23 (1): 3-14.

Vince Pallua, Jelka. 2014. Zagonetka virdžine: Etnološka i kulturnoantropološka studija. Zagreb: Institut društvenih nauka Ivo Pilar.

Von Hahn, Johann Georg. 1867. Reise durch die Gebiete des Drin und Wardar. In Auftrage derk. Akademie der Wissenschaften unternommen im Jahre 1863. Wien: Aus der K.K. Hof- und Staatsdruckerei.

Vukanović, Tatomir P. 1961. Virdžine. Glasnik Muzeja Kosova i Metohije 6: 79-120.

Yanagisako, Sylvia Junko, and Jane Fishburne Collier. 1987. Toward a Unified Analysis of Gender and Kinship. In Gender and Kinship, eds. Jane Fishburne Collier and Sylvia Junko Yanagisako, 14-50. Stanford: Stanford University Press.

Young, Antonia. 1998. “Sworn virgins”: Cases of Socially Accepted Gender Change. Anthropology of East Europe Review 16 (1): 59-75.

Young, Antonia. 2000. Women who Become Men: Albanian Sworn Virgins. Oxford: Berg. DOI: https://doi. org/10.2752/9781847888990. 


\section{ZAPRISEŽENE DEVICE V BALKANSKEM VISOKOGORJU}

Nekoč razširjene zaprisežene device so izginile kot posebna, živa družbena skupina. Raziskave tega fenomena so trdile, da je prisega temeljila na družbenih ali ekonomskih zahtevah skupnosti ali pa je bil razlog pomanjkanje moških. V razpravi raziskovalca trdita, da funkcija prisege ni bila skrivanje dekliškega pravega spola, temveč zakrivanje družbene anomalije, namreč pomanjkanja posebnega moškega, tj. zagovornika hišelgospodinjstvaldružine, zgleda čednosti, poguma, moči in časti. $Z$ domnevo, da je v funkciji nadzora anomalije prisega nedolžnosti reševala čast določene družine (ali klana), je mogoče pojasniti večino primerov tega pojava.

Ritual prisege nedolžnosti je izgubil prvotno funkcijo zaradi številnih dejavnikov, najpomembnejša pa sta dva: država je namesto gospodinjstev, klanov ali skupnosti postopoma začela zagotavljati in uveljavljati pravo; $z$ industrijsko modernizacijo so postale te skupnosti manj izolirane, različni zunanji vplivi so spodbudili spremembe družbene vloge ženske, predvsem večje ženske pravice.

Osnovna omejitev raziskave je, da ni mogla temeljiti na terenskih raziskavah. Tudi v primeru, da zaprisežene device še obstajajo, ne vemo, kako se je pojav preoblikoval v sodobnosti, saj te skupnosti niso več izolirane, hkrati pa ni mogoče prepoznati relevantnih vplivov. Naposled pa je treba tudi terenske podatke raziskovalcev jemati z mero pridržkov, saj te skupnosti niso bile nikoli posebej odprte do tujcev.

Dr. Marija Brujić, University of Belgrade, Department of Ethnology and Anthropology, Faculty of Arts, marija.brujic@f.bg.ac.rs

Dr. Vladimir Krstić, Nazarbayev University, School of Sciences and Humanities, vladimir.krstic@nu.edu.kz 